\title{
Immunoglobulin Pattern in Monoclonal Gammopathy Disorders
}

\author{
Tarek $\mathrm{M}^{1}$, Rahman L ${ }^{2}$, Giti S ${ }^{3}$, Wahab MA ${ }^{4}$
}

DOI: https://doi.org/10.3329/jafmc.v14i2.45899

\begin{abstract}
Introduction: The presence of abnormal monoclonal proteins, the $M$ band, is a frequent characteristic feature of plasma cell dyscrasias and is usually detected as a discrete band in the $y$ or $\beta$ region in serum or urine protein electrophoresis. It is characterized and confirmed by immunofixation electrophoresis (IFE). Accurate detection and quantification of monoclonal immunoglobulins are important for the diagnosis and management of monoclonal gammopathies.
\end{abstract}

Objectives: To find out the pattern of immunoglobulin in monoclonal gammopathy cases and evaluate the role of IFE in the detection of them.

Materials and Methods: This cross-sectional descriptive study was conducted in the Department of Haematology, Armed Forces Institute of Pathology (AFIP), Dhaka from July 2015 to December 2015. Thirty diagnosed cases of monoclonal gammopathies of both sexes were selected. Bone marrow examination, serum protein electrophoresis, skeletal survey, relevant biochemical test and IFE were performed for all the cases.

Results: Out of 30 monoclonal gammopathy cases, M band was identified in $24(80 \%)$ cases by serum protein electrophoresis but by the IFE $M$ band was found in all $30(100 \%)$ cases. Among the M band pattern of immunoglobulin was characterized by IFE and the result was; $15(50 \%)$ cases IgG Kappa, 09(30\%) cases IgG Lambda, 02(6.7\%) cases IgA Kappa, 02(6.7\%) cases IgM Kappa and 02(6.7\%) cases light chain kappa monoclonal protein.

Conclusion: Though the number of the patient was limited, it is evident that in $20 \%$ gammopathy cases $\mathrm{M}$ band was missing by conventional serum protein electrophoresis but IFE could identify $\mathrm{M}$ band in all the cases. It is recommended that IFE should be carried out in all monoclonal gammopathy patients.

Key-words: Monoclonal gammopathy, Immunoglobulin, Immunofixation electrophoresis.

\section{Introduction:}

Monoclonal gammopathy is defined as the electrophoretically and antigenically homogeneous protein product of a single clone of $B$ lymphocytes or plasma cells. The presence of abnormal monoclonal proteins is referred to as monoclonal gammopathy, is a frequent, characteristic feature of plasma cell dyscrasias. The monoclonal protein is usually detected as a discrete band in the y or $\beta$ region in serum or urine protein electrophoresis ( $M$ spike). The nature of the monoclonal protein is then characterized and confirmed by an immunofixation electrophoresis (IFE). Accurate detection and quantitation of monoclonal immunoglobulins are important for the diagnosis and management of monoclonal gammopathies ${ }^{1,2}$. In particular, monoclonal immunoglobulins can be used for screening, monitoring and treatment of diseases and for monitoring progression of diseases in monoclonal gammopathy of unknown significance (MGUS). Approximately $30 \%$ of monoclonal gammopathy patients (including patients with light chain myeloma, primary or amyloid light chain (AL) amyloidosis, non-secretory myeloma, and light chain deposition disease) produce free light chains (FLC) as the only monoclonal component 3 .

The study of monoclonal gammopathy offers an excellent example of how the clinician and the laboratory physician can work together productively. The detection of $\mathrm{M}$ band is often a casual finding in a routine workup and can point the clinician towards the diagnosis; on the other hand, the search for $M$ band is often suggested by the clinical picture. Samples for serum electrophoresis are analyzed for $\mathrm{M}$ band positivity, bone marrow study, biochemical tests and for correlation with clinical profile of the patients. The prevalence of this disease is about $1 \%$ of all the cancers but the incidence increases after the age of 60 years. Normally the plasma cells constitute $1 \%$ of the cells in the bone marrow, but as the disease progresses, the tumour load in the bone marrow increases up to $80 \%$, depending upon the disease severity. These malignant plasma cells synthesize monoclonal antibodies which are released into the circulation. Therefore, this monoclonal protein (antibody) level in the serum increases ${ }^{4}$.

The IFE technique combines zone electrophoresis with immunoprecipitation and is easier and more useful than other techniques. By IFE, proteins of a sample are identified according to their charge separated by electrophoresis on the agarose film, and then they are fixed with monospecific polyclonal antisera. The monoclonal paraproteins can be heavy chain of

1. Lt Col Monwar Tarek, MBBS, DCP, MCPS, FCPS, Classified Specialist in Pathology, AFIP, Dhaka (E-mail: tarekmonwar70@gmail.com) 2. Lt Col Latifa Rahman, MBBS, MPH, MPhil, Associate Professor of Community Medicine, AFMC, Dhaka 3. Maj Gen Susane Giti, MBBS, MCPS, FCPS, Commandant, AFIP, Dhaka 4. Lt Col Md Abdul Wahab, MBBS, MD, Associate Professor of Biochemistry, AFMC, Dhaka. 
$\lg G$, IgA, $\lg M, \lg D$, $\lg E$ and or light chain kappa or lambda. IFE is more sensitive and may reveal an immunoglobulin missed out by conventional protein electrophoresis, especially at low concentrations. To know the pattern of immunoglobulin in monoclonal gammopathy cases and evaluate the role of IFE in detection of different immunoglobulin pattern in monoclonal gammopathy cases.

\section{Materials and Methods}

This cross-sectional descriptive study was conducted in the Department of Haematology, Armed Forces Institute of Pathology (AFIP), Dhaka from July 2015 to December 2015. Total of 30 diagnosed patients of monoclonal gammopathies aged between 40-70 years irrespective of sex were selected for the study. Patients with plasma cell dyscrasia with other malignancy were excluded. Baseline information was collected by face-to-face interview using a standard structured questionnaire. The general medical condition of the patients was evaluated through history, clinical examination and laboratory investigation. Bone marrow aspiration, serum protein electrophoresis, IFE, skeletal survey and relevant biochemical tests were performed for all patients. Protein electrophoresis of the samples was performed by automated capillary electrophoresis machine (Capiflex-2) which identifies the various protein bands and depicts as a graph. The $\mathrm{M}$ band is usually found in the gamma globulin region but in a few cases it is identified in the beta region also. The machine identifies the $\mathrm{M}$ protein both qualitatively and quantitatively. IFE was also performed by the same capillary electrophoresis machine. IFE identifies the type of heavy ( $\lg G, \lg M$ or $\lg A)$ and light chain (either kappa or lambda).

\section{Results}

The study revealed that the mean age of the patients was $57.13 \pm 9.66$ years and majority $(56.7 \%)$ belonged to 60 70 years' age range. About $63 \%$ patients were male with a male-female ratio 1.72:1 (Table-I). Bone marrow study found about $73.3 \%$ cases were multiple myeloma and serum protein electrophoresis found $\mathrm{M}$ band in $80 \%$ cases but IFE found $\mathrm{M}$ band in all 30 cases. Among the $\mathrm{M}$ band pattern of immunoglobulin was characterized by IFE and the result was; 15(50\%) cases IgG Kappa, 09(30\%) cases IgG Lambda, 02(6.7\%) cases IgA Kappa, 02(6.7\%) cases IgM Kappa and 02(6.7\%) cases light chain kappa monoclonal protein (TableII). Biochemical changes according to different immunoglobulin pattern are shown in Table -III. In IgG Kappa renal insufficiency $33.3 \%$, hypercalcaemia $40 \%$, BJP $26.7 \%$. In IgG lambda renal insufficiency $77.7 \%$, hypercalcaemia 44.4\%, BJP 44.4\%. In IgM Kappa Hypercalcaemia 50\%. In IgA Kappa renal insufficiency is $100 \%$, Hypercalcaemia $50 \%$, BJP $100 \%$. In light chain kappa monoclonal gammopathy renal insufficiency 100\%, Hypercalcaemia 100\%, BJP 100\% (Table-III). In IgG Kappa; Multiple myeloma 11, Smoldering multiple myeloma 2, MGUS 2. In IgG lambda; Multiple myeloma 6 and MGUS 3. In IgM
Kappa; Multiple myeloma 2. In IgA Kappa; Multiple myeloma 2. In kappa light chain; multiple myeloma 2 (Table-IV).

Table-l: Distribution of patients according to age and $\operatorname{sex}(n=30)$

\begin{tabular}{|l|l|c|c|}
\hline \multicolumn{2}{|c|}{ Characteristics } & Frequency & Percentage \\
\hline \multirow{4}{*}{ Age (years) } & $40-49$ & 07 & 23.3 \\
\cline { 2 - 4 } & $50-59$ & 06 & 20.0 \\
\cline { 2 - 4 } & $60-70$ & \multicolumn{2}{|c|}{$57.13 \pm 9.66$} \\
\cline { 2 - 4 } & Mean \pm SD & 19 & 63.0 \\
\hline \multirow{2}{*}{ Sex } & Male & 11 & 37.0 \\
\cline { 2 - 4 } & Female & \multicolumn{2}{|c|}{}
\end{tabular}

Table-Il: Laboratory findings of patients $(n=30)$

\begin{tabular}{|c|c|c|c|}
\hline \multicolumn{2}{|l|}{ Characteristics } & Frequency & Percentage \\
\hline \multirow{3}{*}{$\mathrm{Hb} \%$} & Below $9 \mathrm{gm} / \mathrm{dl}$ & 18 & 60.0 \\
\hline & $\begin{array}{l}\text { Between } 9 \mathrm{gm} / \mathrm{dl} \text { to lower } \\
\text { normal range }\end{array}$ & 6 & 20.0 \\
\hline & Within Normal reference & 6 & 20.0 \\
\hline \multirow{5}{*}{ PBF } & Anaemia of chronic disorder & 15 & 50.0 \\
\hline & $\begin{array}{l}\text { Microcytic hypochromic } \\
\text { blood picture with high ESR }\end{array}$ & 05 & 16.7 \\
\hline & $\begin{array}{l}\text { Neutrophil leucocytosis with } \\
\text { high ESR }\end{array}$ & 04 & 13.3 \\
\hline & None specific findings & 03 & 10.0 \\
\hline & $\begin{array}{l}\text { Leuco-erythro-blastic blood } \\
\text { picture }\end{array}$ & 03 & 10.0 \\
\hline \multirow{3}{*}{$\begin{array}{l}\text { Bone Marrow } \\
\text { Study }\end{array}$} & $\begin{array}{l}\text { Suggestive of Multiple } \\
\text { myeloma (bone marrow } \\
\text { plasma cell >20\%) }\end{array}$ & 22 & 73.3 \\
\hline & $\begin{array}{l}\text { Plasma Cell dyscrasia (bone } \\
\text { marrow plasma cell }<20 \% \text { ) }\end{array}$ & 06 & 20.0 \\
\hline & Secondary Reactive Marrow & 02 & 6.7 \\
\hline \multirow{2}{*}{$\begin{array}{l}\text { Serum } \\
\text { electrophoresis }\end{array}$} & Monoclonal band (M band ) & 24 & 80.0 \\
\hline & Normal findings & 06 & 20.0 \\
\hline \multirow{5}{*}{$\begin{array}{l}\text { Type of } \\
\text { monoclonal } \\
\text { protein by IFE }\end{array}$} & IgG Kappa & 15 & 50.0 \\
\hline & IgG Lambda & 09 & 30.0 \\
\hline & IgA Kappa & 02 & 06.7 \\
\hline & IgM Kappa & 02 & 06.7 \\
\hline & Light chain Kappa & 02 & 06.7 \\
\hline \multirow{2}{*}{$\begin{array}{l}\text { Osteolytic } \\
\text { lesion }\end{array}$} & Present & 22 & 73.3 \\
\hline & Absent & 08 & 26.7 \\
\hline \multirow{2}{*}{$\begin{array}{l}\text { Serum } \\
\text { Creatinine }\end{array}$} & $\leq 2.0 \mathrm{mg} / \mathrm{dl}$ & 14 & 46.7 \\
\hline & $>2.0 \mathrm{mg} / \mathrm{dl}$ & 16 & 53.3 \\
\hline \multirow{2}{*}{ Urine for BJP } & Present & 17 & 56.7 \\
\hline & Absent & 13 & 43.3 \\
\hline \multirow{2}{*}{ Serum Calcium } & $\leq 11.0 \mathrm{mg} / \mathrm{dl}$ & 16 & 53.3 \\
\hline & $>11.0 \mathrm{mg} / \mathrm{dl}$ & 14 & 46.7 \\
\hline
\end{tabular}

Table-III: Distribution of biochemical change in different immunoglobulin pattern

\begin{tabular}{|l|c|c|c|r|r|r|}
\hline \multirow{4}{*}{ Biochemical change } & \multicolumn{6}{|c|}{ Serum immunoglobulin pattern in monoclonal gammopathy } \\
\cline { 2 - 7 } & $\begin{array}{c}\text { IgG Kappa } \\
(\mathrm{n}=15)\end{array}$ & $\begin{array}{c}\text { IgG } \\
\text { Lambda } \\
(\mathbf{n}=9)\end{array}$ & $\begin{array}{c}\text { IgM } \\
\text { Kappa } \\
(\mathrm{n}=2)\end{array}$ & $\begin{array}{c}\text { IgA } \\
\text { Kappa } \\
(\mathbf{n}=2)\end{array}$ & $\begin{array}{c}\text { Light chain } \\
\text { Kappa } \\
(\mathrm{n}=2)\end{array}$ & Total \\
\cline { 2 - 8 } & $\begin{array}{c}\text { Frequency } \\
(\%)\end{array}$ & $\begin{array}{c}\text { Frequency } \\
(\%)\end{array}$ & $\begin{array}{c}\text { Frequency } \\
(\%)\end{array}$ & $\begin{array}{c}\text { Frequency } \\
(\%)\end{array}$ & $\begin{array}{c}\text { Frequency } \\
(\%)\end{array}$ & \\
\hline Renal insufficiency & $5(33.3)$ & $7(77.7)$ & 0 & $2(100)$ & $2(100)$ & 16 \\
\hline Hypercalcaemia & $6(40.0)$ & $4(44.4)$ & $1(50.0)$ & $1(50)$ & $2(100)$ & 14 \\
\hline BJP & $8(53.3)$ & $4(44.4)$ & 0 & $2(100)$ & $2(100)$ & 16 \\
\hline
\end{tabular}


Table-IV: Diagnosis of monoclonal gammopathy cases according to different immunoglobulin pattern

\begin{tabular}{|l|c|c|c|c|c|}
\hline \multirow{2}{*}{$\begin{array}{c}\text { Pattern of } \\
\text { monoclonal } \\
\text { immunoglobulin }\end{array}$} & \multicolumn{5}{|c|}{ Diagnosis } \\
\cline { 2 - 6 } & Multiple & $\begin{array}{c}\text { Smoldering } \\
\text { multiple } \\
\text { myeloma }\end{array}$ & MGUS & $\begin{array}{c}\text { kappa } \\
\text { light chain } \\
\text { multiple } \\
\text { myeloma }\end{array}$ & Total \\
\hline IgG Kappa & 11 & 2 & 2 & 0 & 15 \\
\hline IgG Lambda & 6 & 0 & 3 & 0 & 9 \\
\hline IgM Kappa & 2 & 0 & 0 & 0 & 2 \\
\hline IgA Kappa & 2 & 0 & 0 & 0 & 2 \\
\hline Light chain Kappa & 0 & 0 & 0 & 2 & 2 \\
\hline Total & 21 & 2 & 5 & 2 & 30 \\
\hline
\end{tabular}

\section{Discussion}

In this study, the mean age was $57.13 \pm 9.66$ and majority (56.7\%) was $60-70$ years' age group. Male predominance (63\%) male to female ratio was 1.72: 1. A similar study by Shaheen et $\mathrm{al}^{5}$ reported that the mean age of the patients was 58 years and male to female ratio was $1.35: 1$, which is consistent with this study. In a study by Talerman, anaemia was present on admission in $74 \%$ of cases and was severe (below $9 \mathrm{gm} / \mathrm{dl}$ ) in $50 \%{ }^{6}$ and also consistent with the study by Shaheen et al ${ }^{5}$, where haemoglobin was below normal in $90 \%$ and $<8.5 \mathrm{gm} / \mathrm{dl}$ was in $39 \%$ patients. In this study, the peripheral blood film at diagnosis, $15(50 \%)$ revealed anaemia of chronic disorder, 05(16.7\%) were microcytic hypochromic blood picture with high ESR, 04(13.3\%) were neutrophil leucocytosis with high ESR, 03(10\%) were none specific findings and 03(10\%) were Leuco-erythro-blastic blood picture. This study shows bone marrow findings at diagnosis, majority 22(73.3\%) were found suggestive of multiple myeloma, followed by $06(20 \%)$ were found plasma cell dyscrasia and 02(6.7\%) were secondary reactive marrow. Yasseen MK et $\mathrm{al}^{7}$ reported that in serum protein electrophoresis: monoclonal M-band was found in 30(93.75\%) patients of the studied group, in present study serum protein electrophoresis at diagnosis found in $24(80 \%)$.

In the present study, out of 30 monoclonal gammopathy cases, $M$ band (monoclonal protein) identified $24(80 \%)$ by conventional serum protein electrophoresis but by the IFE method found the presence of $\mathrm{M}$ band (monoclonal protein) $30(100 \%)$ cases. Among the M band (monoclonal protein) also categories/ pattern by immunofixation method. The present study detected immunoglobulin pattern by IFE, which indicated predominance of $\lg G$ Kappa monoclonal protein (50\%), followed by IgG Lambda monoclonal protein (30\%), IgA Kappa monoclonal protein (6.7\%), IgM Kappa monoclonal protein $(6.7 \%)$ and Light chain kappa monoclonal protein (6.7\%), and Giti S et al ${ }^{8}$ also reported lgG kappa monoclonal protein in $80 \%$ of cases and IgG lambda monoclonal protein in $20 \%$ of cases which is almost similar to the study by Katzmann et al ${ }^{9}$. The study found IFE confirmed all 169 serum M-spikes in his study as monoclonal proteins which had $100 \%$ specificity.
Serum IFE method is considered the Gold standard ${ }^{10,11}$ with high sensitivity and specificity to detect a small monoclonal protein early and to distinguish the heavy chains from light chains present in the serum and urine of a patient with monoclonal gammopathy. In this study, monoclonal band was detected in all (30) cases by serum IFE technique, whereas serum protein electrophoresis (SPEP) method could detect $24(80 \%)$ cases only. So in the remaining 06 cases $(20 \%)$, a small sharp spike of monoclonal band was found by IFE method whereas, SPEP technique could not detect those cases. A study by Tate et al $^{12}$ reported that serum protein electrophoresis detected $\mathrm{M}$ protein $74.3 \%-87.0 \%$. But in addition of IFE increased this proportion to $97.4 \%$, but the majority of those missed M-proteins MGUS at low risk of progression to Multiple myeloma. A study by Riccaracdi et al13 reported that out of 561 monoclonal gammopathies patients, $\lg G$ was found $71.47 \%$, $\lg A$ was $18.36 \%$ and $\lg M \quad 4.27 \%$. A study by Khan and Bina confirmed that IFE is the only method required to identify IgM paraproteins, with a detection limit of $\leq 0.25 \mathrm{~g} / \mathrm{L}$ even when the concentration of polyclonal immunoglobulin is increased ${ }^{14}$. A study by Youinou et $\mathrm{al}^{15}$ reported that out of 219 monoclonal gammopathies patients, $\lg \mathrm{G}$ was found $51.40 \%$, IgA was $21.49 \%$ and $\lg \mathrm{M} 22.89 \%$. A study by Steingrimsdottir et al ${ }^{16}$ revealed that the type of paraprotein was $\lg A$ in $33.5 \%$, $\lg$ in $57 \%$ and $\lg M$ in $8.5 \%$ of cases. This study shows the urine for Bence Jones protein was present among 17(56.7\%) among the study population. Youinou et $a^{15}$ study reported Bence Jones proteinuria was detected $51.1 \%$ of cases, which is similar to the findings of this study. This study shows serum albumin level at diagnosis $70 \%$ were $<3.5 \mathrm{mg} / \mathrm{dl}$ and $30 \%$ were $>3.5 \mathrm{mg} / \mathrm{dl}$ which is similar to Shaheen et al ${ }^{5}$ and Lakshminarayan et al ${ }^{17}$.

\section{Conclusion}

In spite of the limited number of patients from this study, it was evident that in $20 \%$ gammopathy cases $\mathrm{M}$ band was missing by conventional serum protein electrophoresis but IFE could identify $\mathrm{M}$ band in all the cases. It is recommended that IFE should be carried out in all monoclonal gammopathy patients. The simplicity and economy of the method and the clarity of final results suggest that immunofixation should be considered as a possible successor for the study of monoclonal proteins.

\section{Reference}

1. Durie BG, Kyle RA, Belch A et al. Myeloma management guidelines: a consensus report from the Scientific Advisors of the International Myeloma Foundation. Hematol J 2003; 4:379-98.

2. Guidelines Working Group of UK Myeloma Forum; British Commitee for Standards in Haematology, British Society for Haematology. Guidelines on the diagnosis and management of $\mathrm{AL}$ amyloidosis. Br J Haematol 2004; 125:681-00.

3. Bradwell AR, Mead GP, Carr-Smith HD. Serum Free Light Chain Analysis, 215. The Binding Site, Ltd., Birmingham, UK 2005:1-4. 
4. Mehta KD, Khambu B, Lakhey M et al. Diagnosis of multiple myeloma by demonstration of $\mathrm{M}$ protein in bone marrow aspirate by agar gel electrophoresis: A case report. Kathmandu Univ Med J (KUMJ) 2006; 4(4):513-6.

5. Shaheen H, Ghanghroo I, Malik I. Clinicopathological features and management of Pakistani patients with multiple myeloma. J Pak Med Assoc 1999; 49(10):233-37.

6. Talerman A. Clinico-Pathological study of multiple Myeloma in Jamaica, Pathology Department, University of the West Indies, Kingston, Jamaica, 1969; 22(1):285-93.

7. Yasseen MK. Skeletal Manifestations and Role of Dexa Study in 32 Patients with Multiple Myeloma. Iraqi Academic Scientific Journal 2007; 6(4):307-13.

8. Giti S, Rahman MM, Islam MS et al. The role of serum protein electrophoresis in the detection of multiple myeloma. Bangladesh Armed Forces Medical Journal 2012; 2(1):37-41.

9. Katzmann JA, Stankowski-Drengler TJ, Kyle RA et al. Specificity of serum and urine protein electrophoresis for the diagnosis of monoclonal gammopathies. Clinical Chemistry 2010; 56(12):1899900.

10. Bender LM, Cotten SW, Fedoriw Y et al. Evaluation of digital image for identification and characterization of monoclonal immunoglobulins by immunofixation. Clin Biochaem 2013; 46(3):255-8.
11. Hungria VTM, Crusoe EQ, Quero M et al. Guidelincs on the diagnosis and management of multiple myeloma. Rev res Haematol Haemoter 2013; 35(3):201-17.

12. Tate J, Mollee P, Johnson R. Monoclonal Gammopathies- Clinical and Laboratory Issues. Clin Biochem Rev 2009; 30(8):89-91.

13. Riccaracdi A, Ucci U, Luoni $R$ et al. Bone marrow biopsy in monoclonal gammopathies: Correlations between pathological findings and clinical data. J clin Pathol 1990; 43:469-75.

14. Khan SN, and Bina M. Sensitivity of immunofixation electrophoresis for detecting IgM Paraproteins in serum. CLIN CHEM 1988; 34(8):1633-35.

15. Youinou P, Le PG, Saleun JP et al. Monoclonal gammapathies. (Critical review of 219 cases collected over 3 years). PathologieBiologie 1977; 25(8):517-21.

16. Steingrimsdottir $\mathrm{H}$, Haraldsdottir V, Olafsson I et al. Monoclonal gammopathy: Natural history studied with a retrospective approach. Haematologica 2007; 92:1131-4.

17. Lakshminarayanan $R$, Yueju L, Janatpour $K$ et al. Detection by immunofixation of $\mathrm{M}$ proteins in hypogammaglobulinemic patients patients with normal serum protein electrophoresis results. Am J Clin Pathol 2007; 127:746-51. 